\title{
AZ INFORMÁCIÓ-TÚLTERHELÉS CSÖKKENTÉSE TUDÁSINTENZÍV SZERVEZETEKBEN
}

Tudásintenzív szervezetekben az információ a szervezeti vagyon meghatározó tényezôje. Kezelése viszont sok nehézséget támaszt, elsôsorban növekvố komplexitása miatt, amivel az információ-rendszerek fejlódése sem mindig képes lépést tartani. Az egyik legfóbb, ebból fakadó probléma az információ-túlterhelés, amely az alkalmazottak terhelésének növekedése mellett a szervezet alkalmazkodókészségét, illetve versenyelónyét is veszélyeztetheti. A cikkben bemutatott megközelítés innovatív technológiák használatával segíti a releváns információk megkeresését, kezelését szervezeti kontextusban. E megoldás vezetók számára kiemelten fontos tanulsága, hogy egy egységes fogalmi modellre épített egységes információkezeléssel, ennek eredményeképpen egyfajta tudáskodifikáció, tudásstrukturálás segítségével jelentôsen támogatható a szervezeti tudás megórzése és gyarapítása.

Kulcsszavak: információ-túlterhelés, tudásmenedzsment, tudáskodifikáció, szemantikus technológiák, ontológiák

Az információ a szervezetek vagyonának egyik legfontosabb összetevője, értéke a versenyképesség meghatározó tényezője, emiatt az információmenedzsmentet stratégiai funkciónak kell tekintenünk minden információ- és tudásintenzív szervezetben. Az információ növekvő komplexitása és az egyes problémák megoldására hivatott információrendszerek változatossága viszont jelentôsen megnehezíti az információ megfelelő kezelését. Az információmenedzsment fontos eszközét képező információrendszerek már nem minden esetben képesek követni és leképezni az egyre bonyolultabbá és tudásintenzívebbé váló folyamatokat. A hagyományos, algoritmikus logikára épülő rendszerek hatékonysága, sôt hatásossága is sokszor megkérdőjelezhetô. Az információ és a tudás ugyanakkor jelentős hozzáadott értéket képvisel a szervezeti folyamatokban - feltéve, ha léteznek olyan eszközök, amelyekkel ez megfelelő formában tárolható, kezelhető és visszakereshetô. A hagyományos értelemben tekintett információrendszerek éppen az ilyen komplex információt, tudást igénylő feladatok támogatásában mutatnak jellemző́n alacsonyabb szintú képességeket.

Ez két olyan problémát vet fel, amely a szervezetek többségét érinti. Az egyik az információ-túlterhelés, amely veszélyeztetheti a gazdasági és piaci környe- zetben bekövetkezett változásokhoz történó alkalmazkodás képességét, a versenyelónyt, valamint az alkalmazottak terhelését is jelentôs mértékben növelheti. A másik probléma - amely részben az elózó következménye - a szervezet múködési hatékonyságának romlása, ami jellemzôen abból fakad, ha a megfelelô információ, illetve tudás nem áll rendelkezésre a szervezeti folyamatok megfelelő pontjain. E két probléma hátterében az információ és a tudás változásainak kezelése, illetve ennek hatékonysága is meghúzódik, amely egyre jelentősebb területe az információmenedzsmentnek.

A gazdaság, a technológia és az informatika fejlődése megköveteli a gyors alkalmazkodás képességét mind az egyénektől, mind pedig a szervezetektól, egyre nagyobb iramot diktálva. A másik oldalon viszont szúk keresztmetszetet képez az ember korlátozott információ- feldolgozó képessége, amely alig képes lépést tartani a különféle rendszerek által ontott információtömeggel.

Szükségszerú tehát, hogy az információ-rendszerek fejlődésének olyan irányzatai kerüljenek előtérbe, amelyek innovatív technológiák alkalmazásával a releváns információk fellelését teszik lehetôvé, akár egyének, akár szervezetek számára. 
Ezekre a kihívásokra ad választ az a megközelítés, amely a SAKE ${ }^{1}$-projekt keretei között készült el. Ennek célja egy olyan tudásalapú keretrendszer kifejlesztése volt, amely innovatív technológiák alkalmazásával megfelelóen rugalmasan alkalmazható az elektronikus közigazgatás változó és változatos környezetében, illetve a követelmények sokféleségében. Bár a projekt a közigazgatás területét célozta meg, eredményei, tudásmenedzsmentre alapuló megközelítése és a kifejlesztett rendszer általánosítható és bármilyen szervezet esetében alkalmazható.

A cikk további részében ismertetésre kerül az alkalmazott alapvető terminológia, meghatározva az információ és a tartalom fogalmát az információ-túlterhelés oldaláról vizsgálódva. Ezután azok a módszerek, illetve e alá, amelyekkel a szervezet résztvevôi az információkat elérik, majd megvizsgáljuk e módszerek kiegyensúlyozásának, és így a túlterhelés csökkentésének kérdését. Ezt részletesebb vizsgálat követi a szervezetekben alkalmazott tipikus információforrások és azok kezelésének oldaláról a SAKE-projekt megközelítésében, amit a módszer próbájának tapasztalatai és konklúziója zár.

\section{Információ-túlterhelés}

Ahogy Butcher (1998: p. 53.) is állítja, az információtúlterhelésnek nem létezik általánosan elfogadott meghatározása. A jelenséget leíró kifejezéseket, szinonimákat talán Klausegger et al. (2007, p. 695.) gyújtötte össze a legalaposabban. A sokféle kifejezést vizsgálva látható, hogy nagy számban jelenik meg a túlterhelés okozójaként az információ mellett az adat, sốt a tartalom is a szakirodalom szóhasználatában (,,adatszmog”, „adatrobbanás”, „tartalom-túlterhelés”). Látható tehát, hogy az „információ-túlterhelés” elnevezés mindössze a gyakorlati szóhasználatában elterjedt megnevezés, a jelenség megértéséhez mélyebbre kell ásnunk.

Ackoff (1989) szerint az információ az adattal ellentétben, azon túlmenóen valamilyen jelentést hordoz, amely az információdarabok közötti kapcsolatokból, relációkból származik. Bellinger et al. (2009) is megerôsíti, hogy létezô kapcsolatok, relációk nélkül nem lehet információnak tekinteni semmilyen adatot vagy jelhalmazt, hiszen teljes egészében újdonságot tartalmaznak, azaz nincsen olyan ismeretalap, amelyhez köthetók lennének. Az információ az adatból származik, ami valamilyen feldolgozást tesz szükségessé. Tudásról akkor beszélünk, ha az információt valamilyen meghatározott kontextusban alkalmazzuk (Ackoff, 1989). Ebból következóen a túlterhelés mint probléma forrása a feldolgozásban keresendő. módszerek túlterhelést okozó problémái kerülnek górcsô

A tartalom fogalma kissé eltérő jelentést hordoz. A szótár szerint a tartalom ,minden, ami egy gyújtemény része” (Wordnet, 2008), illetve „mindazon anyagok, beleértve szöveget és képet, amelyek egy publikációt vagy dokumentumot alkotnak" (Houghton Mifflin Company, 2004). Az utóbbi meghatározás nyilvánvalóan a szöveges tartalomra fókuszál, amely a szervezeti tartalmak talán legnagyobb részét képezi. A definíciók általánossága miatt érdemes bevezetni a fogalomhasználat néhány megszorítását, azaz a továbbiakban a tartalom az alapvetôen szöveges, digitális tartalmat jelenti. Az ilyen módon értelmezett tartalom fontossága egyre növekszik, valamint ez dolgozható fel információ-rendszerek segítségével. Az előállított és elérhető tartalom mennyisége bámulatos mértékben növekszik - részben az alacsony elóállítási költségek miatt -, ami nagymértékben hozzájárul a túlterhelés kialakulásához. Itt kell megjegyeznünk azt is, hogy az információ előállításának egyre csökkenó költsége növeli az információ feldolgozásának költségeit, hiszen ez a legtöbb esetben emberi munkát igényel.

A túlterhelés alapvetóen többletet feltételez, ami szükséges, viszont még nem elégséges feltétele a jelenségnek. A szükséges feltétel az ember jelenléte, aki képtelen kezelni a többletet, reagálni arra valamilyen hátrányos következmény nélkül (Himma, 2007: p. 264-266.). A szúkös erőforrás az emberi agy információ-feldolgozó képessége, vagy más szóval a figyelem (Miller, 1956; Jones, 2003; Alvarez-Franconeri, 2007). „A figyelem az, ami a lehetséges és elérhetô több millió információegységból kiválasztja a lényegeseket, az emlékezetból pedig az esemény kiértékeléséhez szükséges utalásokat és emlékeket eleveníti fel, hogy aztán meghozhassa a szükséges döntést." (Csíkszentmihályi, 1990: p. 59.) Ahogy Davenport - Beck (2001: p. 3.) hozzáteszi: „Manapság a figyelem az üzletek és egyének valódi pénzeszköze." A figyelem és az információ mennyisége közötti összefüggést mutatja be az 1 . ábra, szembeállítva a figyelem állandó mértékét az információ exponenciális növekedésével.

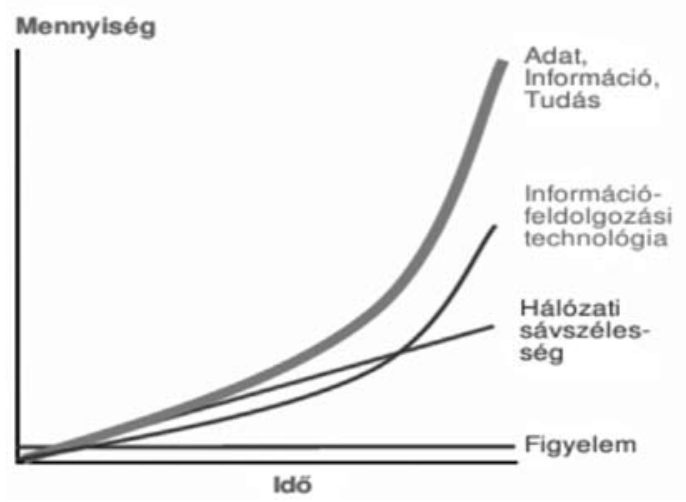

VEZETÉSTUDOMÁNY 
A fentiek alapján a digitális tartalom tekinthetô az adat, információ, sốt a tudás legelterjedtebb platformjának, a túlterheléses szituáció okaként pedig az ember szúkös információ-feldolgozó képességét jelölhetjük meg. Ezek alapján látható, hogy a tartalom-túlterhelés kifejezés pontosabban írná le a jelenséget, de tekintve az információ-túlterhelés megnevezés elterjedtségét a hétköznapi életben és a szakirodalomban egyaránt, a továbbiakban ezt fogjuk használni.

\section{Az információ elérése}

Mindennapjaink során az információ elérésének kétféle módja, az információszállítás (information push) és információkeresés (information pull) megközelítése között egyensúlyozunk. Az információszállítás legegyszerúbb formája megfigyelhetô a rádió, televízió egyirányú múködésében, illetve az e-mail vagy az RSS hírcsatornák múködésében. E megközelítést használva a küldő, a tartalom tulajdonosa értesíthet másokat valamilyen figyelmet igénylő dologról. A tartalom tulajdonosának szemszögéból nézve e megközelítés előnye, hogy sokkal hatékonyabb az ilyen irányú kommunikáció, mint ha a megcélzott partner kezébe adná annak lehetőségét, hogy megkeresse a kérdéses információt. Mivel azonban mind több tartalomtulajdonos választja ezt a módszert, a címzettek túlterheltté válnak, ami szúrést, vagy egyszerúen figyelmen kívül hagyást von maga után. Ez okozta az információszállítás mint technológia jelentőségének csökkenését.

Az információkeresést legjobban az internetes keresốmotorok reprezentálják. Internet uralta világunkban jelenleg ezek nyújtják az információkeresés legegyszerúbb és leghatékonyabb módját. E keresômotorok általában a teljes szöveges keresés módszerét alkalmazzák - néhányuk esetében kategorizálással is kiegészítve -, amelynek hatásossága erôsen függ az alkalmazott kulcsszavaktól. Ha nem megfelelő kulcsszavakat használunk, az eredmények sok zajt tartalmaznak irreleváns találatok formájában. E probléma gyökerei a homonimák és szinonimák által jelentett félreérthetőségben rejlenek (Kovács, 2008: p. 8.). Az információ strukturálása megoldást jelenthet erre a problémára, amit alapszinten a kategorizálás bevezetésével gondoltak sokhelyütt megoldani. Ez elvben könnyebbé tenné a szükséges információ fellelését, ám a megközelítés Kovács (2008) által vizsgált problémái miatt ez mégsem valósul meg.

A szervezeti kontextust vizsgálva az információszállítás technológiáját több szinten is tetten érhetjük. Magasabb szinten tipikus alkalmazási területét jelentik a munkafolyamat- (workflow) rendszerek, hiszen egy munkafolyamat a munka szervezésének, kontrolljának információszállítási (push) megközelítésének is tekinthetô. A munkafolyamat legfóbb feladata a pontos ügymenet biztosítása, amelynek során minden tevékenység bemenetét és kimenetét ellenôrizni, a tevékenységek közötti átmeneteket pedig irányítani kell (Stojanovic et al., 2008). A tevékenységek bemeneti oldalának vezérlése nem más, mint a szükséges inputok megjelenítése a felhasználó számára, azaz a bemenetek szállítása (push). Egy technológiailag ,ideális” állapotban a felhasználónak nem kell információt keresnie, hiszen a munkafolyamat-rendszer minden, a munkához szükséges információt szállít számára.

\section{Az információkeresés formái}

A folyamatok komplexitása határozza meg a folyamatleírások, azaz az egyes feladatok és az átmenetek formalizáltságának mértékét. Algoritmizálható folyamat esetén annak minden lépése leírható, míg egy tudásintenzív folyamat - mint például egy döntés-elökészítés - esetében csupán a folyamat keretei formalizálhatók. Az ilyen folyamatok esetén tehát mindenképpen szükség van az információkeresés alkalmazására, amelynek a következő két alapvető formáját különböztethetjük meg egy szervezetben.

Ha egy feladat ellátásához nem áll rendelkezésre elegendő információ, akkor a hiányzó információt meg kell keresni a rendelkezésre álló információforrásokban. Az ilyen esetekben a munkavégzés támogatható a munkafolyamat-rendszer segítségével, amely biztosítja a feladatleírásokat és a szükséges bemeneti információk egy részét is. Bizonyos mértékig támogatható továbbá tudásintenzív feladatok megoldása is, hiszen amikor további információk keresése szükséges, a keresés során a munkavégző orientálható különböző útmutatásokkal - vagy más szofisztikált eszközökkel -, hogy hol és hogyan nézzen utána a szükséges információnak. Fontos, hogy ez csak akkor múködhet, ha a munkafolyamat jól definiált. Ezt az esetet tekinthetjük a szervezeti információkeresés ,jó” típusának.

Az információkeresés másik, gyakran megfigyelhetô típusa, amikor az információkeresés szükségessége nem egy adott feladat komplexitásának eredménye, hanem a folyamat formalizálásának hiányából fakad. Ebben az esetben formalizált folyamatok és munkafolyamatok helyett a szervezet belsố múködése rosszul koordinált, azaz a feladatokat ad-hoc módon oldják meg, a munkavállalók folyamatosan információ után kutatnak, hiszen a munkájuk nincs megfelelően támogatva, vezérelve. Mivel a feladatok rosszul, hiányosan definiáltak, nem lehet specifikus útmutatást adni, ami segítené, orientálná a munkavégzốt az információkeresés során. Ezt az ese- 
tet tekinthetjük a szervezeti információkeresés „,rossz” típusának. Ilyen eset állhat elő akkor, ha a szervezet folyamatai rosszul vagy nem tudatosan szervezettek, vagy ha a folyamatok a részt vevő egyének kikristályosodott, szokássá szilárdult rutinjára épül.

\section{Az információszállitás és -keresés egyensúlya}

Mivel a szervezetek nem tekinthetôk statikus entitásoknak, a változások természetszerúleg befolyásolják az információszállítás és -keresés alkalmazott mértékét. Ez azt jelenti, hogy az elóbb említett, technológiailag ,ideális” esethez képest az információkeresés mértéke növekszik, ahogy a szervezet új tevékenységeket vezet be. Ha az így létrehozott eljárások, folyamatok már kialakultnak, érettnek tekinthetők, célszerű ezeket formalizálni jól definiált szervezeti folyamatok és az ezeket magába foglaló munkafolyamat formájában. Ez természetesen csökkenti az információkeresés szerepét, teret adva a munkafolyamat által képviselt információszállításnak.

Ez a folyamat tekinthető a szervezet tanulási folyamatának is, hiszen a személyes információkeresési stratégiákat és legjobb gyakorlatokat emeli be a szervezeti memóriába (Huber, 1991). Különösen fontos a szervezet számára, hogy hosszú távon is képes legyen a céljait betölteni, és hatásosan és hatékonyan múködhessen.

A szervezeti tanulás tehát felfogható egyfajta kapocsként az információszállítás és -keresés között, ami a két megközelítés egyensúlyát idóben dinamikussá is teszi. A tanulási folyamat célja, hogy a ,rossz" típusú információkeresés mértékét folyamatosan csökkentse. E nézet szerint a szervezeti tanulás ekvivalens az üzleti folyamatok kialakításával, azaz a személyes tudás és legjobb gyakorlatok explicit formába történô formalizálásával, ami a későbbiekben elősegítheti az automatizálást is.

A két megközelítés közötti másik egyensúlyteremtő tényező a technológia maga. Az információszállítás és -keresés kiegészítik egymást. Ha a munkavégző számára szükséges információt nem tudjuk szállítani, akkor meg kell azt keresnie az információkeresés különböző metódusainak használatával. Eszerint az információszállítás alkalmazott mértéke meghatározza az információkeresés szükséges mértékét is. Az információszállítás mértékének meghatározásához az információ-feldolgozó technológiákat hívhatjuk segítségül. Elvi síkon a két megközelítés egy folytonos skálát határoz meg, aminek információtechnológiai leképezése olyan technológiát igényel, amely kellően skálázható, hogy a két megközelítés bármilyen megkívánt arányát képes legyen kiszolgálni. Ez a technológia szükségsze- rúen magával vonja az információ strukturálását is, ami számos előnye mellett további problémákat is felvet.

Fontos, hogy egyfelól nem minden tartalom kényszeríthetô struktúrába, másfelől pedig egy merev struktúra bevezetése a tudás tacit komponenseinek elvesztését okozhatja. A strukturálás mellett szól annak több előnye is. Mindenekelőtt egyszerúbbé és hatékonyabbá képes tenni a keresést. Strukturálatlan tartalmakban általában szavak és kifejezések előfordulását lehet keresni. Egy struktúrából azonban a struktúra relációi mentén komplexebb információk is kinyerhetók, leszûrhetôk.

A kategorizálás és az általános metaadatkészletek a strukturálás meglehetôsen merev módszerei, amelyek hátrányai veszélyeztetik a technológia fentiekben megkívánt skálázódását. Szükség van olyan eszközre, technológiára, amely rendelkezik a formalizáltság és a struktúra előnyeivel, amelyek kihasználhatók a lekérdezések vagy következtetések során. E követelményeknek megfelelő eszköz az ontológia, mint technológia alkalmazásában található meg.

Az ontológia fogalma a filozófia területéról származik, olyan tudományágat jelölve, amely a létezővel és ezek jellemzőivel foglalkozik - azaz azzal, ,ami van”. Késóbb a mesterséges intelligencia területén terjedt el az ontológia fogalmának használata, a filozófiaitól eltérô jelentéssel. Gruber kiválóan foglalja össze ezt az értelmezést a sokszor idézett definíciójában: ,az ontológia egy fogalmi rendszer explicit leírása" (Gruber, 1993: p. 199.). Borst kiegészíti ezt a definíciót a következóképpen: ,az ontológia egy megegyezéses fogalmi rendszer explicit, formalizált leírása" (Borst, 1997: p. 12.). Itt már közelebb járunk az ontológia jelenlegi alkalmazásához, hiszen a definícióban a formalizáltság azt jelenti, hogy számítógéppel feldolgozható, az explicit szó kifejezi a fogalmak, tulajdonságok, funkciók és axiómák pontos definiálását, a fogalmi modell a világ jelenségeinek egy absztrakt leírása, amely egy közösségben megegyezéssel elfogadottá válik.

Egy ontológiában az osztályok írják le a tulajdonképpeni fogalmakat egy adott szakterületen. Ezek taxonómiába szerveződnek. Ezek a fogalmak (vagy osztályok) a szakterület általános, absztrakt vagy konkrét elemeit képezik le. Az ontológia tulajdonképpen az adott szakterület fogalmainak strukturálásával adja a szakterület formális leírását (Uschold - King, 1995; Gomez-Perez, 1999). A kapcsolatok a szakterület fogalmai közötti interakciókat írják le (Gomez-Perez, 1999). A funkciók vagy attribútumok a fogalmak tulajdonságait, jellemzőit jelenítik meg. Az axiómák igaz logikai állítások egy adott területen, a szabályok pedig a tulajdonságok megszorításait is tartalmazzák (például számosságban, 
típusban). Az egyedek vagy instanciák a konkrét példányokat írják le, mint ahogyan például az áfatörvény a jogszabály fogalom egy példánya.

A tartalom visszakeresésében az ontológia a tartalomelemekhez kapcsolódó metaadatként használható. Az ontológiamodell bármilyen tartalomhoz hozzáigazítható, feloldva ezzel a hagyományos metaadatkészletek merevségét. Az ontológiában definiált relációk, kapcsolatok kihasználhatók a rendszerból történő lekérdezések során. Finomabb részletezettségi szinten az ontológia használható a tartalomnak fogalmakra történô leképezésére, ami például egy szövegben levố kifejezéseknek és mondatoknak az ontológia fogalmaival történő összekötését jelenti, amely fogalmak közötti kapcsolatok, relációk leképezik a tartalom belsô szemantikus struktúráját.

Az ontológiák alkalmazása az elkészítésére tett erôfeszítésekben is skálázható, hiszen a fogalmak és relációik (azaz a logikai állítások) finomsága, granularitása az információ-visszanyerés - azaz a lekérdezések vagy a szervezet igényei szerint megválasztható. Egy részletezettebb ontológia elkészítése természetesen több energiát igényel, aminek a költségvonzata is magasabb.

A bevezetốben említett SAKE-projekt során ez utóbbi, technológiára épüló megoldást valósítottuk meg, amelyet a következő fejezet ismertet részletesebben.

\section{Az információ-túlterhelés csökkentése a SAKE megközelítésében}

Láthattuk, hogy az információ-túlterhelés mérséklésére a technológia oldaláról egyfelől az innovatív technológiákat hívhatjuk segítségül, ami segít az információ strukturálásában, ami alapjául szolgálhat az elózôekben ismertetett technológiai alapú skálázható információszállítási megközelítésnek. Ez azonban még csak a probléma egyik oldala, hiszen ha a szervezet egészét vizsgáljuk, információt és tartalmakat kezelô rendszerek sokféleségével találkozunk, ami szintén hozzájárul a túlterheléshez. Szervezeti szinten ezért a megoldás e rendszerek integrációja az információ szintjén.

Ehhez vagy az információnak kell homogénnek lennie - ami nem megvalósítható, tekintve a rendszerek, illetve rendszerkomponensek sokféleségét -, vagy homogén metaadatokkal kell rendelkezniük, amit a korábban ismertetett ontológiák használatával érhetünk el. Ez utóbbi eljárás látszik megvalósíthatónak, amit alátámaszt hasonló, metaadatokra épülő megoldások elterjedtsége például az adattárházak világában (Inmon, 1996; Chaudhuri - Dayal, 1997; Jarke et al., 2003). Stojanovic et al. (2008) szerint az eképpen értelmezett információintegrációhoz szükség van az információforrások integrálására, az összes információ integrált feldolgozására, valamint az információ kiegészítésére folyamat- és felhasználói kontextusinformációkkal. A következókben ennek módjait vizsgáljuk.

\section{Információforrások a rendszerben}

A SAKE-rendszer - mint keretrendszer - több komponensból áll, amelyek az információintegráció szempontjából információforrásokként vannak jelen. Mindegyik komponens hagyományos információrendszer-funkciókat valósít meg, amelyek a szervezetek valamely igényére adnak választ. Ezeket egészíti ki a keretrendszerben egy ún. szemantikus réteg, amely új szintre emeli a funkcionalitásukat, megvalósítva a fent ismertetett információintegrációt.

Az információ sokhelyütt megtalálható egy szervezetben. Egy része nyilvánvaló formában - mint például a dokumentumokban -, más része rejtettebb módon, például az interperszonális kommunikációban van elrejtve. A SAKE-rendszer komponensei ezeket a különböző információforrásokat képezik le az információrendszerek világára. E megoldás sajátossága, hogy a komponensek hagyományos változatai a legtöbb esetben már rendelkezésre, sốt alkalmazásban állnak sok szervezetben. A SAKE-megközelítés ezen komponensek, illetve az ezekben tárolt információk szemantikus technológiák, ezen belül is ontológiák segítségével történő integrálását célozza.

\section{Szöveges információk}

Az információ és tudás leggyakoribb forrásai csaknem minden szervezetben a dokumentumok - mint például szervezeti szabályzatok, pénzügyi jelentések vagy szerződések -, amelyekben jobbára szöveges tartalmak találhatóak. Ezeket egyszerú szerkeszteni, tartalmukat frissíteni, indexelni, valamint emberi módon, illetve szoftveres eszközökkel feldolgozni. Az ilyen információk kezelésére szolgálnak a tartalomkezelő rendszerek, amelyek persze a legtöbb esetben képesek más tartalomtípusok, például hang- vagy videotartalmak kezelésére is. A manapság használt lekérdezési mechanizmusok azonban leginkább a szöveges tartalmak keresésére adnak megoldást, többnyire a teljes szöveges keresés eszközeinek használatával. Ezt a keresési mechanizmus, bár sokszor elegendően hatékony, a korábban említett hátrányok jellemzik.

A tartalomkezelő rendszer mögötti szemantikus réteg bevezetésével lehetóvé válik a rendszer által kezelt tartalmak, információk ontológiák segítségével történő homogenizálása, az előzőekben ismertetett 
módon. Mindemellett arra is alkalmas, hogy olyan kontextusinformációkkal egészítsük ki a tárolt tartalmakat, mint például az üzleti folyamat aktuális állapota, tevékenysége, illetve a felhasználói adatok.

Az ilyen kiegészítő információk teszik lehetôvé a munkavégző́k terhelésének csökkentését. A tipikus túlterheléses helyzetek többsége megszüntethetô a szemantikus rétegben található kontextusinformációk alapján történő szűréssel, például olyan dokumentumok automatikus ajánlásával, amelyek az aktuális tevékenységet tekintve hasznosak lehetnek. Az ehhez szükséges információ előállítható például más felhasználók használati szokásaiból, vagy magukból a dokumentumokból, indexeléssel, vagy a leghatékonyabb megoldásként a szemantikus annotáció segítségével. Ez utóbbi nem más, mint a tartalom elemeinek és az ontológia fogalmainak összerendelése. Így történhet meg a dokumentumok ontológiai fogalmakra történố leképezése, ami megkönnyíti a feldolgozásukat és visszakeresésüket. Az annotáció eszköze szükséges tehát a keresések pontosításához, a hagyományos módszereknél relevánsabb találatok felkínálásához (Stojanovic et al., 2008). Ez az eljárás alkalmas a túlterhelés csökkentésére, mivel hozzájárul a szükséges információ hatékonyabb felleléséhez.

\section{Együttmúködés}

Egy szervezeten belül általában a kommunikáció jelenti a leggyorsabb reakciót a környezet változásaira, hiszen általában a legaktuálisabb problémák szerepelnek a beszélgetésekben. Látható tehát, hogy az interperszonális kapcsolatok, az emberek közötti együttmúködés is jelentős mértékben hozzájárulhat a szervezet információvagyonához, amennyiben sikerül azt legalább bizonyos mértékig kinyerhetôvé tenni. A SAKE-rendszerben a csoportmunkarendszer támogatja a kommunikációt és a kollaborációt, általános szolgáltatásokat nyújtva, mint amilyenek a fórumok, az osztott naptár és az értesítési szolgáltatások.

A csoportmunkarendszer is csatlakozik az előzőekben már említett szemantikus réteghez, ami a gyakorlatban azt jelenti, hogy minden, a rendszer eszközeivel létrehozott információt tárolunk az ontológiában, kiegészítve kontextusinformációkkal - hasonlóan a tartalomkezelő rendszerhez. Az annotáció eszköze is elérhető egyfajta értékelés formájában, ami az egyes hozzászólásoknak vagy beszélgetéseknek egy probléma megoldása során mutatott hasznosságát hivatott jelezni. A használati szokásokat szintén rögzíti a rendszer az ontológiákban, ami itt is hozzájárul az információk pontosabb visszakereséséhez.
Mindezek alapján látható, hogy ez a komponens nagyban támogatja a változásokhoz történó alkalmazkodást, továbbá a beszélgetésekben jelen levố tudás externalizálását, megragadható formában történő használatát is elősegíti.

\section{Üzleti folyamatok}

Amint azt már láthattuk, az információintegráció egyik kulcseleme az információ kiegészítése kontextusinformációkkal. Az egyik kézenfekvő és talán a legfontosabb ilyen kontextusinformációt az üzleti folyamatok, illetve ennek információ-rendszerekben történő leképezései, valamint az ezeket összefogó munkafolyamatok adják. A SAKE-rendszer a munkafolyamatokat tekinti az egyik legfontosabb kontextusinformációnak, mivel ezek határozzák meg a feladatok végrehajtásának, ügyek megoldásának kereteit. Bizonyos területeken például a közigazgatásban - külsố szabályok, jogi elóírások meghatározzák a folyamatokat, ügymeneteket. Máshol a szervezetnek magának kell ezeket kialakítania, mint azt korábban már láttuk. Mindegyik esetben cél egy folyamatmodell felállítása és egy ezen alapuló munkafolyamat felépítése. A SAKE-rendszer esetében a folyamatokat az ontológia eszközeivel modelleztük, hogy a szemantikus réteg képes legyen ezeket a többi információval együttesen mint információforrást kezelni. A munkafolyamat-motor e modell egy átalakított, egyszerúsített változatát hajtja végre a rendszer múködése során, ami nagyobb teljesítmény elérését teszi lehetôvé az ontológiaalapú végrehajtáshoz képest. A végrehajtás során viszont az ontológiát használjuk a felhasználói és eseményinformációk tárolására, folyamatosan pontos képet adva a folyamat állapotáról a szemantikus rétegben. Ezt az információt használja minden további komponens kontextusinformációként a korábban ismertetett módon.

\section{Külsố információforrások}

Minden szervezet erósen beágyazódik a környezetébe, így annak folyamatos figyelése, monitorozása is fontos feladat, mert a változások jelentős része innen ered. A SAKE-rendszerben a külsố információforrások figyelését a változáskövetố rendszer (change notification system) végzi. Ez jelenleg az elérhető szöveges információkat veszi figyelembe, mint például a próbaüzem folyamán monitorozott jogi forrásokat. Ez a komponens a szervezet és a környezet kapcsolatát, ezáltal a szervezet gyors alkalmazkodókészségét támogatja, a lehető legkevesebb emberi beavatkozást igényelve. Az észlelt változásokat a rendszer a szemantikus rétegbe továbbítja. Sajnos a technológia jelen állása szerint nem valószerú az az elvárás, hogy a külsố 
forrásokat automatikusan képes legyen egy informatikai rendszer feldolgozni és a szervezeti tudás részévé tenni, ezért a rendszerben a változások monitorozásának végső lépése a feldolgozás felelőseinek értesítése.

\section{Az információ feldolgozása}

A SAKE-rendszer egyik fő komponense a figyelemkezelő rendszer (attention management system), amely a szemantikus réteg ontológiái alapján szolgáltat információkat. A komponens fő eleme egy ontológiai következtetőgép, amely előre definiált, illetve ad-hoc módon megadott lekérdezéseket futtatva olyan információkat juttat el a felhasználóhoz, amelyek ezen szabályok és az ontológiában tárolt információk alapján relevánsnak számítanak. Ez a komponens nyújtja a fentebb ismertetett szemantikus funkciókat, mint a dokumentumok vagy kommunikáció kontextus függô ajánlását, vagy a fogalmak szerinti keresést egy adott szakterület tartalmaiban.

\section{A módszertan ellenôrzése}

A SAKE megközelítését három közigazgatási eseten ellenóriztük a projekt folyamán, amelyek három különbözô országban: Magyarországon, Lengyelországban és Szlovákiában találhatók. Ezen országok hasonló problémákkal küzdenek a közigazgatásban, a közszolgáltatások sok területén igyekeznek felzárkózni az EU minôségi kritériumainak követelményeihez. A helyzetüket bonyolítják az előzőekben részletezett információ- és tudásmenedzsment-kihívások, a tevékenységeik komplexitása, a folyamatos környezeti, szabályozási és hatásköri változások. A három közigazgatási szervezetet három különbözô problématerületen vizsgáltuk:

1) A LATA (Mestská čast’ Košice - Sídlisko Ťahanovce) a helyi, kerületi rendeletalkotási folyamatba kívánja bevonni a lakosságot.

2) Az OKM (Oktatási és Kulturális Minisztérium) a felsőoktatási képzési keretszámok tervezését szeretné támogatni azzal, hogy a munkaerô-piaci kereslethez igazítja azokat.

3) Az UMC (Urząd Miasta Częstochowy) az oktatási intézmények anyagi eróforrásainak menedzsmentjét célozta meg.

Mindhárom esetben tudás- és információintenzív folyamatokat dolgoztunk fel, miközben a korábban ismertetett szervezeti problémák merültek fel (Samiotis, 2010):

- mindegyik esetben nagy mennyiségú, sokféle forrásból származó információt és dokumentumot dolgoztak fel, ami nagy munkaterhelést okozott,

- a szervezetek múködési környezete számtalan szállal kapcsolódott a szervezethez, a vizsgált esetekben leginkább jogszabályok és rendeletek játszottak jelentős szerepet,

- a tudásforrásokat jelentő tartalmak folyamatos monitorozása volt szükséges a gyakori változások miatt,

- a jogszabályok értelmezéséhez és alkalmazásához speciális szaktudás volt szükséges, gyakran annak félreérhetôsége, nem triviális értelmezhetôsége miatt,

- a dokumentumok és tartalomelemek logikailag összetartoznak, és gyakran egymástól függnek - ahogy egy rendelet értelmez egy jogszabályt például -, és csak bizonyos komplex alkalmazáskontextusban érvényesek (például milyen régióban, időzítésben, a döntések vagy állampolgárok mely körére alkalmazható).

A próbaüzem eredményei igazolták, hogy a SAKEmegközelítés alkalmas a már ismertetett szervezeti kihívások kezelésére. A tesztelés ugyan a közigazgatás területén történt, a megközelítés általános jellege miatt tetszóleges szervezetnél alkalmazható.

\section{Konklúzió}

A SAKE-megközelítés és tudásmenedzsment keretrendszer alkalmazásából számos tapasztalat leszúrhetô. A próbaüzem igazolta, hogy a megközelítés alkalmas az információszállítás (push) és -keresés (pull) közötti egyensúly kezelésére a munkafolyamat és a szemantikus réteg segítségével.

Ennek vezetők számára fontos következménye, hogy a tesztben részt vevô folyamatok átláthatóbbá és gyorsabbá váltak, illetve a formalizálás miatt könnyebben dokumentálhatók és kontrollálhatók. A tesztelt folyamatokban kodifikált tudás immár explicit tudásként más folyamatokban is használhatóvá vált. Elkészült egy egységes fogalmi keretrendszer az ontológia formájában, ami a rendszerbeli használatán túlmutatóan az adott szakterület más részein is egyértelmúbbé tette a fogalomhasználatot. Ugyanebból kifolyólag rámutatott a használt fogalmi rendszer olyan inkonzisztenciáira is, amit az adott szervezeteknek - néhány esetben a törvényalkotóknak - korrigálniuk kell. Az információ visszakeresését a vizsgált esetekben leginkább a tartalomkezelő rendszer támogatta a tartalmak és az ontológia fogalmainak összerendelése, az annotáció segítségével. Ezen előnyök egy részét - mint amilyen a folyamatok átláthatóbbá tétele - más, korábban elérhető megoldások is képesek voltak nyújtani, viszont az eszközök ilyen 
komplex, szemantikus technológiák segítségével történố összekötése új szintre képes emelni a szervezet hatékonyságát.

A változáskövető rendszer feladata a vizsgált esetekben a jogszabályok változásának figyelése volt, amelynek hasznossága a rendszer említett korlátai miatt csak mérsékelt volt. A döntés-előkészítő folyamatok esetében az érintettek együttmúköódését a csoportmunkarendszer támogatta, míg a folyamat során használt és létrehozott anyagokat a tartalomkezelố rendszer kezelte. A munkafolyamat-rendszer szerepe a vizsgált folyamatok tudás intenzív jellege miatt a keretek kijelölésére szúkült, ám az egyes lépésekben jól használhatónak bizonyult, mint a kontextusinformáció forrása. A rendszerkomponensek által a szemantikus rétegben tárolt használati adatokból a figyelemkezelő rendszer által leszürt információk szintén hasznosnak bizonyultak.

Fontos kiemelnünk tudásintenzív szervezetek vezetôi számára az ismertetett megoldás tudáskodifikációs képességét. A vezetők számára különösen fontos a szervezeti tudás megốrzése, illetve gyarapítása. E megoldás használatával egyrészt explicitté tehető a munkavégzés, ügyintézés rutinjának folyamata, az ebben rejlố tudás. Az ontológia építése lehetôvé teszi másfelól azt is, hogy a szervezet által ismert szakterület(ek) fogalmi rendszerét kodifikálják, alapot nyújtva ezzel a szakterületi tudás megőrzéséhez. Természetesen az ontológia maga is a tudásreprezentáció egyik formája, a szervezet számára mégis ott lesz jelentôs értéke, amikor a fogalmak és a szervezet formális és informális tartalmai (a dokumentumok, tartalmak és a kommunikáció) ehhez kapcsolódva struktúrát nyernek, ami a már részletezett módon jelentôs többletet ad a piacon fellelhetô, hagyományos megoldásokhoz képest.

Mindemellett a SAKE-rendszer és -megközelítés hátrányai is nyilvánvalóvá váltak. Jelentős erőfeszítést igényel a háttér-ontológiák elkészítése, hiszen ezeket a szervezet tevékenységi köre szerinti szakterületekre kell szabni. Nehéz továbbá előre meghatározni és betartani az ontológia megkívánt részletezettségi szintjét, ami viszont befolyásolja az elkészítésre irányuló erófeszítések mértékét. Ezeken felül a próbaüzem során a rendszer használatánál problémát okozott a szükséges alapszintú számítógép-használati ismeretek hiánya. Több felhasználó találta komplexnek és nehéznek a rendszer használatát, amin megfeleló felhasználóifelület-tervezési módszerekkel lehet segíteni. A projekt tapasztalatai azonban sokféle területen alkalmazhatók, bármilyen szervezet számára hasznosak lehetnek.

A megközelítés alkalmazási területét illetôen a rendszerben felhasznált információk széles köre jel- lemző, ezért a megoldás nyilvánvalóan jobban múködhet olyan nagyobb szervezetek esetében, ahol már részben vagy egészben formalizált üzleti folyamatok jellemzőek, vagy ezek használatát fontolgatják. Fontos kiemelni azt is, hogy a rendszer hatékony múködéséhez szükséges az ontológiák aktív használata, különösen a tartalmak és az ontológia fogalmainak összerendelése, ami - lévén a folyamat jelen technológiai szinten még nem automatizálható - eróforrásokat és fegyelmet kíván. Emellé párosul még a szakterületi ontológia kidolgozásának említett magas erőforrásigénye. Mindezek együttesen is a nagyméretú szervezeteket (nagyvállalatokat, illetve a közigazgatást) állítják a felhasználás középpontjába.

\section{Lábjegyzet}

${ }^{1}$ SAKE-Semantic-enabled Agile Knowledge-basede-Government (IST 027128) kutatási projekt egy nemzetközi kutatási konzorcium kivitelezésében, amely az EU 6. Keretprogram Kutatás- és Technológiai Fejlesztés programjának részfinanszírozásában valósult meg. A projekt 2006 márciusában indult, és 36 hónapot ölelt át. További információk a projekt weboldalán találhatók: http://www.sake-project.org.

\section{Felhasznált irodalom}

Ackoff, R.L. (1989): From data to wisdom. Journal of Applied Systems Analysis, 16, p. 3-9.

Alvarez, G.A. - Franconeri, S.L. (2007): How many objects can you track?: Evidence for a resource-limited attentive tracking mechanism, Journal of Vision, 7(13), p. 1-10. http://journalofvision.org/7/13/14/ Letöltve: 2009.03.21.

Bellinger, G. -Castro, D. - Mills, A. (2009): Data, information, knowledge, and wisdom. http://www.systems-thinking. org/dikw/dikw.htm Letöltve: 2009.01.06.

Borst, W.N. (1997): Construction of Engineering Ontologies. $\mathrm{PhD}$ Thesis, University of Tweenty, Enschede, NLCentre for Telematica and Information Technology

Butcher, H. (1998): Meeting managers' information needs. Aslib, London

Chaudhuri, S. - Dayal, U. (1997): An overview of data warehousing and OLAP technology. ACM Sigmod record, 26(1), p. 65-74.

Csíkszentmihályi, M. (1990): Flow: the psychology of optimal experience, Harper and Row, New York

Davenport, T.H. - Beck, J.C. (2001): The Attention Economy: Understanding the New Currency of Business. Harvard Business School Press, Boston

Gomez-Perez, A. (1999): Ontological Engineering: A State Of The Art. Expert Update, 2(3), p. 33-43.

Gruber, T.R. (1993): A Translation Approach to Portable Ontology Specifications. Knowledge Acquisition, 5(2), p. 199-220. 
Himma, K. (2007): The concept of information overload: A preliminary step in understanding the nature of a harmful information-related condition. Ethics and Information Technology, 9(4), p. 259-272.

Houghton Mifflin Company (2004): The American Heritage Dictionary of the English Language. negyedik kiadás, Houghton Mifflin Company. Answers.com. http://www. answers.com/topic/content Letöltve: 2009.01.14.

Huber, G. (1991): Organizational learning: the contributing processes and the literature. Journal of Organizational Science, 2, p. 88-115.

Inmon, W. (1996): The data warehouse and data mining. Communications of the ACM, 39(11), p. 49-50.

Jarke, M. - Lenzerini, M. - Vassiliou, Y. - Vassiliadis, P. (2003): Fundamentals of Data Warehouses. Springer Verlag, München

Jones, D. M. (2003): The New C Standard: A Cultural and Economic Commentary. Addison-Wesley Professional, Upper Saddle River, MA

Klausegger, C. - Sinkovics, R.R. - Zou, H.J. (2007): Information overload: a crossnational investigation of influence factors and effects. Marketing Intelligence \& Planning, 25(7), p. 691-718.
Kovács, B. (2008): Improving content management - a semantic approach, Acta Cybernetica, 18(4), p. 579593.

Miller, G.A. (1956): The magical number seven, plus or minus two: Some limits on our capacity for processing information, The Psychological Review, 63, p. 81-97.

Samiotis, K. (2010): SAKE: Semantic-enabled agile knowledge-based e-government. http://www.epractice. eu/en/cases/sake Letöltve: 2009.01.14.

Stojanovic, N. - Apostolou, D. - Dioudis, S. - Biró, M. - Gábor, A. - Kovács, B. - Butka, P. - Lukac, G. - Siemek, A. - Wozniak, D. - Petrvalsky, E. - Bruhács, T. Kasprzycki, J. (2008): D24 - Integration plan. SAKE Project documentation

Uschold, M. - King, M. (1995): Towards A Methodology for Building Ontologies. IJCAI-95 Workshop on Basic Ontological Issues in Knowledge Sharing, Montreal, Canada

Wordnet (2008): Content. http://wordnet.princeton.edu/perl/ webwn?s=content Letöltve: 2008.11.21.

Cikk beérkezett: 2010. 9. hó

Lektori vélemény alapján véglegesítve: 2010. 10. hó

\section{E SZÁMUNK SZERZÖI}

Ransburg Beatrix, doktorjelölt, Budapesti Múszaki és Gazdaságtudományi Egyetem; Dr. Vágási Mária, egyetemi docens, PhD-témavezetô, Budapesti Múszaki és Gazdaságtudományi Egyetem; Dr. Demeter Krisztina, egyetemi docens, Budapesti Corvinus Egyetem; Losonci Dávid, egyetemi tanársegéd, Budapesti Corvinus Egyetem; Kosztyán Zsolt Tibor, egyetemi docens, Pannon Egyetem; Kiss Judit, PhD-hallgató, Pannon Egyetem; Szúcs Gergely, PhD-hallgató, Budapesti Corvinus Egyetem; Kovács Barna, tudományos munkatárs Budapesti Corvinus Egyetem; Dr. Szintay István, egyetemi tanár, Miskolci Egyetem 